\title{
Erratum to: Functional cine MRI and transabdominal ultrasonography for the assessment of adhesion to implanted synthetic mesh 5-7 years after laparoscopic ventral hernia repair
}

N. B. Zinther · A. Zeuten · E. Marinovskij •

M. Haislund $\cdot$ H. Friis-Andersen

Published online: 26 June 2010

(C) Springer-Verlag 2010

\section{Erratum to: Hernia}

DOI 10.1007/s10029-010-0676-x

In the list of authors of this article, errors have been introduced during data transmission and validation of the accepted text.

The correct list of authors is:

N. B. Zinther, A. Zeuten, E. Marinovskij, M. Haislund and $H$. Friis-Andersen

The online version of the original article can be found under doi:10.1007/s10029-010-0676-x.

N. B. Zinther $(\square) \cdot$ H. Friis-Andersen

Surgical Department, Horsens Regional Hospital,

Sundvej 30, 8700 Horsens, Denmark

e-mail: nellie@zinther.dk

\section{N. B. Zinther}

Scientific Unit, Horsens Regional Hospital,

Sundvej 30, 8700 Horsens, Denmark

\author{
A. Zeuten \\ Radiologic Department, Aarhus University Hospital, \\ Aarhus, Denmark \\ E. Marinovskij · M. Haislund \\ Mr-center, Aarhus University Hospital, Skejby, Denmark
}

